\title{
INFLUENCE OF ORGANIC MANURE, BIOFERTILIZER AND/OR SOME VITAMIN TREATMENTS ON: \\ B. CORM AND CORMELS PRODUCTIVITY AND SOME CHEMICAL CONSTITUENTS OF GLADIOLUS GRANDIFLORUS VAR. GOLD FIELD PLANTS
}

\author{
M.A.H. Abdou; M.K. Aly; A.A. El-Sayed and A.S.A. Ahmed
}

Hort. Dept., Fac. Agric., Minia Univ., Egypt

\begin{abstract}
A field experiment was conducted to investigate the effect of plant farmyard manure (FYM) as an organic fertilizer (0, 10, 15 and $20 \mathrm{~m}^{3} / \mathrm{fed}$ ) and Minia Azotein (M.A.) at $50 \mathrm{ml} /$ plant and/or some vitamins ( $\mathrm{E}$ and $\mathrm{C}$ ) each at $50 \mathrm{ppm}$ on corm and cormels productivity and chemical constituents of Gladiolus grandiflorus var. Gold Field plants. The obtained results indicated that corm diameter (cm), number of cormels/plant, dry weight of corm and cormels (g), as well as, chemical constituents including chlorophyll a, b, carotenoids and percentages of $\mathrm{N}, \mathrm{P}$ and $\mathrm{K}$ in the corms were gradually increased by increasing the levels of FYM. Significant differences were detected among the four used treatments. So, the high level of FYM resulted the highest values. All six treatments of Minia Azotein (M.A.) and/or some vitamins ( $\mathrm{E}$ and $\mathrm{C}$ ) significantly increased corm and cormels productivity and their content of chemical constituents in comparison to the control plants. The treatments of Minia Azotein (M.A.) plus vit.
\end{abstract}

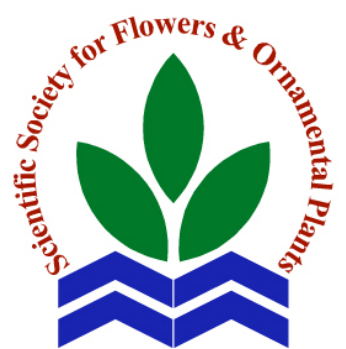

Scientific J. Flowers \& Ornamental Plants, 6(2):125-137(2019).

Received: 15/5/2019

Accepted: 30/5/2019 E plus vit. C was more effective than other treatments for corm and cormels productivity, as well as, photosynthetic pigments content (mg/g. F.W.) and the percentages of nitrogen, phosphorus and potassium, in most cases. The interactions between farmyard manure (FYM), Minia Azotein (M.A.) and/or some vitamins (E and C) treatments were significant for all previous characters, except for $\mathrm{K} \%$. In most cases, the highest values of corm and cormels productivity were achieved by FYM (20 $\left.\mathrm{m}^{3} / \mathrm{fed}\right)$ in combination with Minia Azotein (M.A.) plus vit. E plus vit. C followed by $20 \mathrm{~m}^{3} / \mathrm{fed} \mathrm{FYM} \mathrm{with}$ M.A. + vit. C then $15 \mathrm{~m}^{3} /$ fed FYM with M.A. + vit. E + vit. C which recorded the highest contents of pigments and elements of $\mathrm{N}$ and $\mathrm{P} \%$.

Key words: Gladiolus grandifloras, farmyard manure, biofertilizers, vitamins, corm, cormels, chemical constituents.

\section{INTRODUCTION}

Gladiolus grandiflorus var. Gold Field plant is considered one of the most important flowering bulbs grown in Egypt. There are fast expands in areas planted with gladiolus in Egypt in order to meet the increase demand for gladiolus flowers for local market and exporting, Gladiolus plants are propagated by corms and cormels.

Farmyard manure as organic fertilizer, Minia Azotein (M.A.), vit. E and vit. C are among the important agricultural treatments which have been proved to improve corm production of gladiolus plants. 
The effect of organic fertilization on increasing corm diameter, number of cormels and dry weight of corm and cormels of gladiolus were reported by many investigators, such as Abdou and Ibrahim (2015) and Karagöz et al. (2019) on gladiolus, Abd El-Karim (2001), AbdelSattar et al. (2010), Srivastava et al. (2014) and Pattnaik (2016) on tuberose, El-Naggar and El-Nasharty (2009) on Hippeastrum vittatum, El-Sayed et al. (2012) on Freesia and Prasad et al. (2017) on lily plant who stated that improved the chemical composition of gladiolus plants as well.

Minia Azotein (M.A.) biofertilizer treatment were found to have stimulatory effects on corm and cormels productivity and chemical composition of gladiolus such as those summarized by Abdou et al. (2004), Hassanein and El-Sayed (2009), Mazhar and Eid (2016), Sathyanarayana et al. (2018) and Chakradhar et al. (2019) on gladiolus and Khan et al. (2009) on tulip plant

With regard to corm and cormels productivity, as well as, chemical constituents of gladiolus, some vitamins (E and $\mathrm{C}$ ) treatments were found to increase corm diameter, number of cormels, dry weight of corm and cormels and pigments (chlorophyll a, b and carotenoids contents), as well as, NPK \% (Ramraj et al. (1997), Abdel Aziz et al., 2009 and Abo Leila and Eid, 2011).

The aim of this work was to study the effect of application farmyard manure (FYM) fertilization, Minia Azotein (M.A.) and/or spraying with some vitamins ( $\mathrm{E}$ and C) on corm and cormels productivity, as well as, chemical constituents of Gladiolus grandiflorus var. Gold Field plants.

\section{MATERIALS AND METHODS}

The present study was carried out at the Nursery and Laboratory of Ornamental Plants, Faculty of Agriculture, Minia University during two successive seasons of $2016 / 2017$ and $2017 / 2018$ on gladiolus plants.
Gladiolus grandiflorus var. Gold Field corms were obtained from Holland by Basiony nurseries, Cairo, Egypt. Average corm diameter was 2.7 and $3.3 \mathrm{~cm}$ and corms weight were 9.4 and $10.2 \mathrm{~g}$ for the first and second seasons, respectively. Corms were planted on October $1^{\text {st }}$ for both seasons in 1.5 $\times 2.0 \mathrm{~m}$ plots containing 3 ridges, $50 \mathrm{~cm}$ apart. Corms were planted in hills, $20 \mathrm{~cm}$ apart (10 corms/ridge) at a depth of $5 \mathrm{~cm}$ under ground surface in clay loam soil. The physical and chemical analysis of the used soil in both seasons were determined according to Jackson (1973) and shown in Table (a)

The split plot design with three replicates was followed in this experiment. The four levels of FYM fertilization treatments $\left(0,10,15\right.$ and $20 \mathrm{~m}^{3} /$ fed) were considered as main plots and the seven Minia Azotein (M.A.) and/or some vitamin (E and C) treatments (control, alpha tocopherols (vit. E) at $50 \mathrm{ppm}$, ascorbic acid (vit. C) at $50 \mathrm{ppm}$, Minia Azotein (M.A.) at $50 \mathrm{ml} /$ plant, M.A. + vit. E, M.A. + vit. C and M.A. + vit. E + vit. C) were put in the subplots.

The chemical analysis of FYM was done according to Black et al. (1965) and is shown in Table (b).

Gladiolus plants were inoculated by Minia Azotein (M.A.) biofertilizer at the rate of $50 \mathrm{ml} / \mathrm{hill}$, as well as, some vitamin ( $\mathrm{E}$ and $\mathrm{C}$ ) treatments each at the concentration of $50 \mathrm{ppm}$ were applied, by hand sprayer, 3 times, one month and two months from planting date and after flowers cut for corm and cormels productivity. The plants were sprayed till run off. All agricultural practices were performed as usual in the region. The following data were recorded:

1. Under ground parts characters at harvesting after the foliage had dried (the under ground parts were lifted 2 months after cut spikes): corm diameter (cm), number of new cormels/plant and dry weights of corm and cormels (g). 
Table a. Physical and chemical properties of the experimental soil.

\begin{tabular}{|c|c|c|c|c|c|c|}
\hline \multirow{2}{*}{ Soil character } & \multicolumn{2}{|c|}{ Values } & \multirow{2}{*}{\multicolumn{2}{|c|}{ Soil character }} & \multicolumn{2}{|c|}{ Values } \\
\hline & $2016 / 2017$ & $2017 / 2018$ & & & $2016 / 2017$ & $2017 / 2018$ \\
\hline Sand \% & 28.20 & 28.98 & \multicolumn{2}{|c|}{ Available P \% } & 15.15 & 15.64 \\
\hline Silt \% & 30.70 & 29.87 & \multicolumn{2}{|c|}{ Exchangeable $\mathbf{K}^{+}$} & 2.09 & 2.82 \\
\hline Clay \% & 41.10 & 41.15 & \multicolumn{2}{|c|}{ Exch. $\mathrm{Ca}^{++} \mathrm{mg} / 100$ g soil } & 31.71 & 31.10 \\
\hline Soil texture & Clay loam & Clay loam & \multicolumn{2}{|c|}{ Exch. $\mathrm{Na}^{+} \mathrm{mg} / 100$ g soil } & 2.42 & 2.53 \\
\hline Organic matter \% & 1.59 & 1.56 & & & & \\
\hline $\mathrm{CaCO}_{3} \%$ & 2.08 & 2.10 & & $\mathrm{Fe}$ & 8.52 & 8.22 \\
\hline pH 1:2.5 & 7.80 & 7.77 & DTPA & $\mathbf{C u}$ & 2.05 & 2.02 \\
\hline E.C. m mhose/cm & 1.06 & 1.07 & Ext. ppm & Zn & 2.74 & 2.85 \\
\hline Total N \% & 0.07 & 0.08 & & Mn & 8.24 & 8.09 \\
\hline
\end{tabular}

Table b. Chemical analysis of FYM applied in the present study.

\begin{tabular}{lcclcc}
\hline Properties & $\mathbf{1}^{\text {st }}$ season & $\mathbf{2}^{\text {nd }}$ season & \multicolumn{1}{c}{ Properties } & $\mathbf{1}^{\text {st }}$ season & $\mathbf{2}^{\text {nd }}$ season \\
\hline Organic matter \% & 28.0 & 27.5 & K \% & 1.18 & 1.22 \\
Carbon \% & 15.80 & 16.65 & Fe ppm & 239.0 & 237.5 \\
Total N \% & 0.92 & 0.95 & Zn ppm & 271.2 & 273.1 \\
C/N ratio & 17.17 & 17.53 & Mn ppm & 233.5 & 235.8 \\
Humidity \% & 8.00 & 7.91 & pH & 7.31 & 7.21 \\
P \% & 0.23 & 0.25 & E.C. (mhose/cm) & 1.07 & 1.08 \\
\hline
\end{tabular}

2. Determination of some chemical constituents: leaf samples were taken after 75 days from planting to determine chlorophyll a, b and carotenoids as $\mathrm{mg} / \mathrm{g}$ f.w. using the method described by Fadl and Sari El-Deen (1978). The percentages of $\mathrm{N}, \mathrm{P}$ and $\mathrm{K}$ in the dry corms (samples were taken after two months from flowering end) were estimated according to the methods described by Wilde et al. (1985), Champan and Pratt (1975) and Cottenie et al. (1982), respectively.

All obtained data were tabulated and statistically analyzed according to MSTATC (1986) and the L.S.D. test at $5 \%$ was followed to compare between the means.

\section{RESULTS AND DISCUSSION}

\section{Corm and cormels productivity:}

Data listed in Tables (1 and 2) during both seasons indicated that corm diameter (cm), corm dry weight (g), number of cormels/plant and dry weight of cormels/plant (g) were significantly increased with increasing FYM level in comparison with untreated control plants. Among the three FYM treatments, the high level treatment $\left(20 \mathrm{~m}^{3} / \mathrm{fed}\right)$ resulted the highest values for all corm and cormels productivity over both media ( $\left.15 \mathrm{~m}^{3} / \mathrm{fed}\right)$ and low $\left(10 \mathrm{~m}^{3} /\right.$ fed) FYM treatments in the two seasons. Similar results were also revealed on gladiolus plants Ahmed (2013), Abdou and Ibrahim (2015) and Karagöz et al. (2019) on gladiolus, Abd El-Karim (2001), Abdel-Sattar et al. (2010), Srivastava et al. (2014) and Pattnaik (2016) on tuberose, ElNaggar and El-Nasharty (2009) on Hippeastrum vittatum, El-Sayed et al. (2012) on Freesia and Prasad et al. (2017) on lily plant.

The increase in the corm and cormels productivity was attributed to the positive effect of organic fertilizers on improving the vegetative growth, as well as, stimulating the photosynthetic pigments (Table, 3) which reflected on increasing the under ground parts of gladiolus. 
Table 1. Effect of farmyard manure (FYM), biofertilizer and/or some vitamin treatments, as well as, their combination treatments on corm diameter $(\mathbf{c m})$ and corm dry weight (g) of Gladiolus grandiflorus var. Gold Field during the first and second seasons.

\begin{tabular}{|c|c|c|c|c|c|c|c|c|c|c|}
\hline \multirow{3}{*}{$\begin{array}{l}\text { Biofertilization } \\
\text { and some vitamin } \\
\text { treatments (B) }\end{array}$} & \multicolumn{10}{|c|}{ FYM levels (m³/fed) (A) } \\
\hline & \multicolumn{5}{|c|}{$1^{\text {st }} \operatorname{season}(2016 / 2017)$} & \multicolumn{5}{|c|}{$2^{\text {nd }}$ season $(2017 / 2018)$} \\
\hline & $\mathbf{0}$ & 10 & 15 & 20 & $\begin{array}{c}\text { Mean } \\
\text { (B) }\end{array}$ & $\mathbf{0}$ & 10 & 15 & 20 & $\begin{array}{c}\text { Mean } \\
\text { (B) }\end{array}$ \\
\hline \multicolumn{11}{|c|}{ Corm diameter (cm) } \\
\hline Control & 3.34 & 3.74 & 4.19 & 4.32 & 3.90 & 3.42 & 3.82 & 4.25 & 4.59 & 4.02 \\
\hline Alpha tocopherol (vit. E) & 3.63 & 3.90 & 4.30 & 4.65 & 4.12 & 3.71 & 4.07 & 4.52 & 4.82 & 4.28 \\
\hline Ascorbic acid (vit. C) & 3.81 & 4.26 & 4.60 & 4.98 & 4.41 & 3.92 & 4.47 & 4.81 & 5.33 & 4.63 \\
\hline Minia Azotein (M.A.) & 4.23 & 4.53 & 4.93 & 5.18 & 4.72 & 4.36 & 4.78 & 5.12 & 5.43 & 4.92 \\
\hline M.A. + vit. E & 4.25 & 4.85 & 5.15 & 5.27 & 4.88 & 4.39 & 4.99 & 5.42 & 5.52 & 5.08 \\
\hline M.A. + vit. C & 4.52 & 5.07 & 5.25 & 5.35 & 5.04 & 4.68 & 5.38 & 5.45 & 5.62 & 5.28 \\
\hline M.A. + vit. E + vit. C & 4.82 & 5.20 & 5.32 & 5.47 & 5.20 & 4.90 & 5.44 & 5.59 & 5.91 & 5.46 \\
\hline Mean (A) & 4.08 & 4.51 & 4.82 & 5.03 & & 4.20 & 4.71 & 5.02 & 5.32 & \\
\hline L.S.D. at $5 \%$ & \multicolumn{2}{|c|}{ A: 0.19} & B: 0.07 & \multicolumn{2}{|c|}{ AB: 0.14} & \multicolumn{2}{|c|}{ A: 0.24} & B: 0.16 & \multicolumn{2}{|c|}{ AB: 0.32} \\
\hline \multicolumn{11}{|c|}{ Corm dry weight (g) } \\
\hline Control & 29.0 & 31.3 & 34.7 & 38.7 & 33.4 & 40.3 & 44.3 & 48.3 & 50.3 & 45.8 \\
\hline Alpha tocopherol (vit. E) & 31.0 & 34.3 & 38.0 & 42.9 & 36.6 & 44.0 & 46.2 & 50.0 & 54.0 & 48.6 \\
\hline Ascorbic acid (vit. C) & 31.4 & 37.7 & 42.7 & 46.0 & 39.4 & 45.0 & 49.7 & 53.7 & 57.0 & 51.3 \\
\hline Minia Azotein (M.A.) & 34.8 & 41.3 & 45.3 & 49.7 & 42.8 & 48.5 & 53.0 & 56.8 & 59.1 & 54.4 \\
\hline M.A. + vit. E & 35.0 & 44.7 & 49.4 & 54.7 & 45.9 & 48.8 & 55.3 & 57.9 & 61.7 & 55.9 \\
\hline M.A. + vit. C & 41.0 & 46.9 & 53.0 & 55.3 & 49.1 & 51.7 & 57.3 & 61.0 & 63.0 & 58.3 \\
\hline M.A. + vit. E + vit. C & 44.0 & 50.0 & 55.0 & 58.3 & 51.8 & 54.4 & 59.7 & 62.7 & 66.3 & 60.8 \\
\hline Mean (A) & 35.2 & 40.9 & 45.4 & 49.4 & & 47.5 & 52.2 & 55.8 & 58.8 & \\
\hline L.S.D. at $5 \%$ & \multicolumn{2}{|c|}{ A: 3.8} & $\mathrm{~B}: 1.7$ & \multicolumn{2}{|c|}{ AB: 3.4} & \multicolumn{2}{|c|}{ A: 3.0} & B: 1.9 & \multicolumn{2}{|c|}{ AB: 3.8} \\
\hline
\end{tabular}

In relation to Minia Azotein (M.A.) and/or some vitamin (E and $\mathrm{C}$ ) treatments, the six treatments significantly suppressed, the control treatment in both first and second seasons in producing wider corm, higher new cormels/plant and heavier dry weights of corms and cormels as shown in Tables (1 and 2). Among the six treatments, the combined Minia Azotein (M.A.) with vitamin $E$ plus vitamin $C$ gave the highest values for corm and cormels productivity. Similar observations about the role of biofertilizer were pointed out on gladiolus plants such as Abdou et al. (2004), Hassanein and El-Sayed (2009), Mazhar and
Eid (2016), Sathyanarayana et al. (2018) and Chakradhar et al. (2019) on gladiolus and Khan et al. (2009) on tulip plant. The role of vitamin $\mathrm{E}$ in promoting corm and cormels productivity was mentioned by Ramraj et al. (1997) on potato plant. Also, the role of vitamin $C$ was found by Abdel Aziz et al. (2009) and Abo Leila and Eid (2011) on gladiolus, El-Morsy et al. (2010) and Shalaby and El-Ramady (2014) on garlic and Abo-Hinna and Merza (2012) on potato.

The stimulatory effect of Minia Azotein (M.A.) on corm and cormels production may be due to their mode of action, nutrient uptake and regulation of photosynthesis and 
Table 2. Effect of farmyard manure (FYM), biofertilizer and/or some vitamin treatments, as well as, their combination treatments number of cormels and cormels dry weight (g) on of Gladiolus grandiflorus var. Gold Field during the first and second seasons.

\begin{tabular}{|c|c|c|c|c|c|c|c|c|c|c|}
\hline \multirow{3}{*}{$\begin{array}{l}\text { Biofertilization } \\
\text { and some vitamin } \\
\text { treatments (B) }\end{array}$} & \multicolumn{10}{|c|}{ FYM levels ( $\left.\mathrm{m}^{3} / \mathrm{fed}\right)(\mathrm{A})$} \\
\hline & \multicolumn{5}{|c|}{$1^{\text {st }}$ season $(2016 / 2017)$} & \multicolumn{5}{|c|}{$2^{\text {nd }}$ season $(2017 / 2018)$} \\
\hline & $\mathbf{0}$ & 10 & 15 & 20 & $\begin{array}{l}\text { Mean } \\
\text { (B) }\end{array}$ & $\mathbf{0}$ & 10 & 15 & 20 & $\begin{array}{l}\text { Mean } \\
\text { (B) }\end{array}$ \\
\hline \multicolumn{11}{|c|}{ Number of cormels } \\
\hline Control & 22.8 & 26.7 & 29.4 & 31.9 & 27.7 & 24.6 & 29.2 & 30.7 & 34.0 & 29.6 \\
\hline Alpha tocopherol (vit. E) & 25.2 & 28.1 & 31.4 & 34.2 & 29.7 & 27.6 & 30.2 & 33.1 & 36.5 & 31.9 \\
\hline Ascorbic acid (vit. C) & 27.0 & 31.1 & 33.2 & 36.1 & 31.9 & 29.5 & 32.4 & 35.8 & 39.3 & 34.2 \\
\hline Minia Azotein (M.A.) & 30.1 & 32.6 & 36.1 & 38.6 & 34.3 & 31.6 & 35.6 & 38.6 & 40.7 & 36.6 \\
\hline M.A. + vit. E & 30.3 & 35.8 & 37.5 & 39.1 & 35.7 & 31.9 & 37.5 & 40.3 & 44.9 & 38.6 \\
\hline M.A. + vit. C & 32.5 & 36.6 & 39.0 & 42.2 & 37.6 & 35.1 & 39.9 & 44.5 & 47.3 & 41.7 \\
\hline M.A. + vit. E + vit. C & 34.9 & 38.7 & 41.5 & 42.6 & 39.4 & 37.0 & 42.9 & 46.4 & 48.0 & 43.5 \\
\hline Mean (A) & 29.0 & 32.8 & 35.4 & 37.8 & & 31.0 & 35.4 & 38.5 & 41.5 & \\
\hline L.S.D. at $5 \%$ & \multicolumn{2}{|c|}{ A: 1.8} & B: 0.9 & \multicolumn{2}{|c|}{ AB: 1.8} & \multicolumn{2}{|c|}{ A: 2.8} & B: 1.2 & \multicolumn{2}{|c|}{ AB: 2.4} \\
\hline \multicolumn{11}{|c|}{ Cormels dry weight (g) } \\
\hline Control & 10.97 & 12.56 & 13.73 & 14.90 & 13.04 & 12.06 & 14.12 & 15.16 & 16.42 & 14.44 \\
\hline Alpha tocopherol (vit. E) & 11.80 & 13.22 & 14.67 & 16.01 & 13.93 & 13.34 & 14.82 & 16.26 & 17.77 & 15.55 \\
\hline Ascorbic acid (vit. C) & 12.98 & 14.60 & 15.97 & 17.01 & 15.14 & 14.50 & 15.67 & 17.56 & 19.05 & 16.70 \\
\hline Minia Azotein (M.A.) & 14.13 & 15.31 & 16.91 & 18.00 & 16.09 & 15.18 & 17.31 & 18.96 & 19.62 & 17.77 \\
\hline M.A. + vit. E & 14.48 & 16.72 & 17.59 & 18.39 & 16.79 & 15.31 & 18.21 & 19.60 & 22.01 & 18.78 \\
\hline M.A. + vit. C & 15.23 & 17.15 & 18.32 & 19.73 & 17.61 & 17.16 & 19.36 & 21.48 & 22.99 & 20.25 \\
\hline M.A. + vit. E + vit. C & 16.23 & 18.08 & 19.36 & 20.01 & 18.42 & 17.80 & 20.75 & 22.24 & 23.37 & 21.04 \\
\hline Mean (A) & 13.69 & 15.38 & 16.65 & 17.72 & & 15.05 & 17.18 & 18.75 & 20.18 & \\
\hline L.S.D. at $5 \%$ & \multicolumn{2}{|c|}{ A: 0.95} & B: 0.75 & \multicolumn{2}{|c|}{$\mathrm{AB}: 1.50$} & \multicolumn{2}{|c|}{ A: 1.25} & B: 0.66 & \multicolumn{2}{|c|}{ AB: 1.32} \\
\hline
\end{tabular}

growth. Consequently increase in all corm production (Dadarwall et al., 1997, Hauwaka, 2000 and Gadagi et al., 2004).

In plants, $\alpha$-tocopherol an ascorbic acid are believed to promote the corm and cormels productivity (Munne-Bosch and Algere, 2002 and Eid et al., 2010).

The interaction between FYM, Minia Azotein (M.A.) and/or some vitamin (E and C) treatments was significant for corm diameter, number of cormels/plant and dry weights of corm and cormels per plant in the two seasons (Tables 1 and 2). In most cases, the highest values were obtained for all corm and cormels productivity parameters when gladiolus plants received farmyard manure (FYM) at $20 \mathrm{~m}^{3} / \mathrm{fed}$ in combination with Minia Azotein (M.A.) plus vit. E plus vit. C followed by $20 \mathrm{~m}^{3} /$ fed with M.A. + vit. C then $15 \mathrm{~m}^{3} /$ fed with M.A. + vit. E + vit. C.

\section{Chemical constituents:}

\section{a. Photosynthetic pigments:}

The contents of chlorophyll a, b and carotenoids in the fresh leaves of Gladiolus grandiflorus var. Gold Field were significantly promoted due to FYM treatments, in the two growing seasons, in comparison with those of untreated plants as 
Table 3. Effect of farmyard manure (FYM), biofertilizer and/or some vitamin treatments, as well as, their combination treatments photosynthetic pigments content (mg/g F.W.) on of Gladiolus grandiflorus var. Gold Field during the first and second seasons.

\begin{tabular}{|c|c|c|c|c|c|c|c|c|c|c|}
\hline \multirow{3}{*}{$\begin{array}{l}\text { Biofertilization } \\
\text { and some vitamin } \\
\text { treatments (B) }\end{array}$} & \multicolumn{10}{|c|}{ FYM levels ( $\left.\mathrm{m}^{3} / \mathbf{f e d}\right)(\mathrm{A})$} \\
\hline & \multicolumn{5}{|c|}{$1^{\text {st }}$ season $(2016 / 2017)$} & \multicolumn{5}{|c|}{$2^{\text {nd }}$ season $(2017 / 2018)$} \\
\hline & $\mathbf{0}$ & 10 & 15 & 20 & $\begin{array}{c}\text { Mean } \\
\text { (B) }\end{array}$ & $\mathbf{0}$ & 10 & 15 & 20 & $\begin{array}{c}\text { Mean } \\
\text { (B) }\end{array}$ \\
\hline \multicolumn{11}{|c|}{ Chlorophyll a content (mg/g F.W.) } \\
\hline Control & 2.281 & 2.322 & 2.360 & 2.410 & 2.343 & 2.290 & 2.330 & 2.371 & 2.419 & 2.352 \\
\hline Alpha tocopherol (vit. E) & 2.318 & 2.358 & 2.398 & 2.439 & 2.378 & 2.327 & 2.367 & 2.415 & 2.449 & 2.389 \\
\hline Ascorbic acid (vit. C) & 2.348 & 2.396 & 2.438 & 2.475 & 2.414 & 2.357 & 2.407 & 2.447 & 2.489 & 2.425 \\
\hline Minia Azotein (M.A.) & 2.379 & 2.425 & 2.458 & 2.487 & 2.437 & 2.388 & 2.431 & 2.470 & 2.502 & 2.448 \\
\hline M.A. + vit. E & 2.388 & 2.450 & 2.485 & 2.516 & 2.460 & 2.399 & 2.465 & 2.500 & 2.528 & 2.473 \\
\hline M.A. + vit. C & 2.420 & 2.478 & 2.514 & 2.546 & 2.489 & 2.430 & 2.490 & 2.527 & 2.561 & 2.502 \\
\hline M.A. + vit. E + vit. C & 2.449 & 2.507 & 2.534 & 2.564 & 2.513 & 2.460 & 2.522 & 2.549 & 2.583 & 2.528 \\
\hline Mean (A) & 2.369 & 2.419 & 2.455 & 2.491 & & 2.379 & 2.430 & 2.468 & 2.504 & \\
\hline L.S.D. at $5 \%$ & \multicolumn{2}{|c|}{ A: 0.032} & B: 0.023 & \multicolumn{2}{|c|}{ AB: 0.046} & \multicolumn{2}{|c|}{ A: 0.035} & B: 0.026 & \multicolumn{2}{|c|}{ AB: 0.052} \\
\hline \multicolumn{11}{|c|}{ Chlorophyll b content (mg/g F.W.) } \\
\hline Control & 0.741 & 0.753 & 0.766 & 0.780 & 0.760 & 0.744 & 0.758 & 0.771 & 0.787 & 0.765 \\
\hline Alpha tocopherol (vit. E) & 0.746 & 0.763 & 0.777 & 0.793 & 0.770 & 0.757 & 0.770 & 0.785 & 0.793 & 0.776 \\
\hline Ascorbic acid (vit. C) & 0.754 & 0.776 & 0.793 & 0.806 & 0.7 & 0.766 & 0.783 & 0.792 & 0.811 & 0.788 \\
\hline Minia Azotein (M.A.) & 0.767 & 0.7 & 0.800 & 0.809 & 0.791 & 0.775 & 0.792 & 0.805 & 0.816 & 0.797 \\
\hline M.A. + vit. E & 0.772 & 0.797 & 0.809 & 0.819 & 0.799 & 0.779 & 0.804 & 0.815 & 0.828 & 0.807 \\
\hline M.A. + vit. C & 0.783 & 0.807 & 0.818 & 0.830 & 0.809 & 0.791 & 0.813 & 0.826 & 0.839 & 0.817 \\
\hline M.A. + vit. E + vit. C & 0.794 & 0.816 & 0.825 & 0.835 & 0.818 & 0.798 & 0.822 & 0.837 & 0.850 & 0.827 \\
\hline Mean (A) & 0.765 & 0.786 & 0.798 & 0.810 & & 0.773 & 0.792 & 0.804 & 0.818 & \\
\hline L.S.D. at $5 \%$ & A: 0.0 & & B: 0.007 & $\mathrm{AB}$ & 0.014 & A: 0. & & B: 0.009 & $\mathrm{AF}$ & 0.018 \\
\hline \multicolumn{11}{|c|}{ Carotenoids content (mg/g F.W.) } \\
\hline Control & 0.782 & 0.793 & 0.812 & 0.822 & 0.802 & 0.786 & 0.801 & 0.814 & 0.832 & 0.808 \\
\hline Alpha tocopherol (vit. E) & 0.792 & 0.807 & 0.818 & 0.831 & 0.812 & 0.799 & 0.813 & 0.826 & 0.841 & 0.820 \\
\hline Ascorbic acid (vit. C) & 0.802 & 0.817 & 0.828 & 0.846 & 0.823 & 0.810 & 0.824 & 0.839 & 0.852 & 0.831 \\
\hline Minia Azotein (M.A.) & 0.815 & 0.826 & 0.842 & 0.850 & 0.833 & 0.821 & 0.837 & 0.846 & 0.861 & 0.841 \\
\hline M.A. + vit. E & 0.816 & 0.840 & 0.850 & 0.860 & 0.842 & 0.822 & 0.845 & 0.857 & 0.868 & 0.848 \\
\hline M.A. + vit. C & 0.823 & 0.848 & 0.858 & 0.871 & 0.850 & 0.834 & 0.854 & 0.867 & 0.880 & 0.859 \\
\hline M.A. + vit. E + vit. C & 0.836 & 0.857 & 0.865 & 0.876 & 0.858 & 0.843 & 0.864 & 0.878 & 0.891 & 0.869 \\
\hline Mean (A) & 0.809 & 0.827 & 0.839 & 0.851 & & 0.816 & 0.834 & 0.847 & 0.861 & \\
\hline L.S.D. at $5 \%$ & A: 0.0 & & B: 0.006 & $\mathrm{AB}$ & 0.012 & A: $0 .($ & & B: 0.007 & & 0.014 \\
\hline
\end{tabular}


shown in Table (3). The high level of FYM (20 $\mathrm{m}^{3} / \mathrm{fed}$ ) gave the highest values for the three photosynthetic pigments in both seasons. These results may be attributed to the increase in nutrient elements and/or positive role of organic farmyard manure (FYM) on the physical and chemical properties of the soil, that reflected on the growth and the pigments content. In harmony with these results regarding organic fertilization treatments were those reported by Khalil (2015) and Abdou et al. (2018) on gladiolus, El-Naggar and El-Nasharty (2009) on Hippeastrum vittatum, Mathivanan et al. (2012) on ground nut, Dalawai and Naif (2017) on Dianthus caryophyllus,

In relation to the influence of Minia Azotein (M.A.) and/or some vitamin (E and C) treatments on chlorophyll a, b and carotenoids contents were promoted, in the two seasons (Table, 3). Using both Minia Azotein (M.A.) and some vitamins (E and C) together was more effective than the used treatments. Also, the differences between any treatment and control was statistically significant, among the six treatments, Minia Azotein (M.A.) plus some vitamin E plus vitamin $C$ resulted the highest values over all other treatments. These results may be attributed not only to the increase in nutrient elements, but also to the role of Minia Azotein (M.A.) treatment on stomatal regulation and photosynthesis and growth as separately Taha and Hassan (2008) on gladiolus and Attia et al. (2018) on tuberose, Also, vitamin E increased pigments as reported by Hassan (2013) on roselle, Ibrahim (2014) on khella and Mohamed (2016) on Antirrhinum majus plant. Vitamin $\mathrm{C}$ gave similar results obtained by Kasim and Adil (2014) on freesia, Mohammed et al. (2016) on dahlia and Gaber (2019) on Pelargonium zonale plant.

Effects of the interaction between FYM, Minia Azotein (M.A.) and/or some vitamin ( $E$ and $C$ ) treatments were significant in both seasons, for corm diameter, number of cormels/plant and dry weights of corm and cormels with the highest values being obtained due to the use of FYM at $20 \mathrm{~m}^{3} / \mathrm{fed}$ in combination Minia Azotein (M.A.) plus vitamin $\mathrm{E}$ plus vitamin $\mathrm{C}$ followed by 20 $\mathrm{m}^{3} /$ fed with M.A. + vit. C then $15 \mathrm{~m}^{3} / \mathrm{fed}$ with M.A. + vit. E + vit. C, in most cases as shown in Table (3).

\section{b. Nitrogen, phosphorus and potassium percentages:}

In both seasons, increasing the level of FYM linearly increased the percentages of $\mathrm{N}, \mathrm{P}$ and $\mathrm{K}$ in the corms. In this concern, the treatment with high level of FYM (20 $\mathrm{m}^{3} / \mathrm{fed}$ ) gave the highest percentages (Table, 4). On the other hand, the lowest values of $\mathrm{N}, \mathrm{P}$ and $\mathrm{K} \%$ in the corms were recorded by the plants treated with organic fertilization. Moreover, significant differences were detected between FYM treatments and control one, also between FYM treatments in all cases.

The results mentioned above, could be attributed to that application of FYM improved soil properties, increased nutrients in area of roots, which increased nutrients uptake, in turn reflects on the corm quality.

These results are in agreement with those obtained by Sönmez et al. (2013), Khalil (2015), Abdou et al. (2018) on gladiolus, Abd El-Karim (2001) and Suseela et al. (2016) on tuberose, Eliwa et al. (2009) on Iris, El-Sayed et al. (2012) on freesia and Dalawai and Naif (2017) on Dianthus caryophyllus.

The percentages of $\mathrm{N}, \mathrm{P}$ and $\mathrm{K}$ were significantly increased, in both seasons, as a result of inoculating gladiolus with Minia Azotein (M.A.) and spraying gladiolus with some vitamin ( $E$ and $C$ ) treatments in comparison with the control (Table, 4). The treatment of M.A. + vit. E + vit. C recorded the significantly highest values for $\mathrm{N}, \mathrm{P}$ and $\mathrm{K} \%$ in both seasons. $\mathrm{N}$ - fixing bacteria enhance the uptake of different nutrients (Jagnow et al., 1991). Also, alpha tocopherol is involved in a wide range of important functions as antioxidant defense and regulation of photosynthesis and growth (Zhang et al. 2000). Ascorbic acid promoted 
Table 4. Effect of farmyard manure (FYM), biofertilizer and/or some vitamin treatments, as well as, their combination treatments on nitrogen, phosphorus \& potassium percentages of Gladiolus grandiflorus var. Gold Field during the first and second seasons.

\begin{tabular}{|c|c|c|c|c|c|c|c|c|c|c|}
\hline \multirow{3}{*}{$\begin{array}{c}\text { Biofertilization } \\
\text { and some vitamin } \\
\text { treatments }(B)\end{array}$} & \multicolumn{10}{|c|}{ FYM levels (m³/fed) (A) } \\
\hline & \multicolumn{5}{|c|}{$1^{\text {st }}$ season $(2016 / 2017)$} & \multicolumn{5}{|c|}{$2^{\text {nd }}$ season $(2017 / 2018)$} \\
\hline & $\mathbf{0}$ & 10 & 15 & 20 & $\begin{array}{c}\text { Mean } \\
\text { (B) }\end{array}$ & $\mathbf{0}$ & 10 & 15 & 20 & $\begin{array}{c}\text { Mean } \\
\text { (B) }\end{array}$ \\
\hline \multicolumn{11}{|c|}{ N \% } \\
\hline Control & 1.675 & 1.780 & 1.855 & 2.087 & 1.849 & 1.751 & 1.862 & 1.922 & 2.165 & 1.925 \\
\hline Alpha tocopherol (vit. E) & 1.748 & 1.843 & 2.035 & 2.175 & 1.950 & 1.817 & 1.910 & 2.125 & 2.221 & 2.018 \\
\hline Ascorbic acid (vit. C) & 1.808 & 1.993 & 2.154 & 2.293 & 2.062 & 1.886 & 2.074 & 2.216 & 2.366 & 2.136 \\
\hline Minia Azotein (M.A.) & 1.876 & 2.146 & 2.264 & 2.340 & 2.156 & 1.937 & 2.211 & 2.335 & 2.405 & 2.222 \\
\hline M.A. + vit. E & 1.931 & 2.260 & 2.328 & 2.412 & 2.233 & 2.005 & 2.327 & 2.403 & 2.563 & 2.325 \\
\hline M.A. + vit. C & 2.132 & 2.321 & 2.364 & 2.441 & 2.314 & 2.200 & 2.394 & 2.529 & 2.588 & 2.428 \\
\hline M.A. + vit. E + vit. C & 2.207 & 2.360 & 2.438 & 2.461 & 2.367 & 2.289 & 2.420 & 2.585 & 2.611 & 2.476 \\
\hline Mean (A) & 1.911 & 2.100 & 2.205 & 2.316 & & 1.984 & 2.171 & 2.302 & 2.417 & \\
\hline L.S.D. at $5 \%$ & \multicolumn{2}{|c|}{ A: 0.081} & B: 0.011 & \multicolumn{2}{|c|}{ AB: 0.022} & \multicolumn{2}{|c|}{ A: 0.101} & B: 0.012 & \multicolumn{2}{|c|}{ AB: 0.024} \\
\hline \multicolumn{11}{|c|}{$\mathbf{P} \%$} \\
\hline Control & 0.223 & 0.254 & 0.296 & 0.325 & 0.275 & 0.228 & 0.260 & 0.307 & 0.337 & 0.283 \\
\hline Alpha tocopherol (vit. E) & 0.236 & 0.293 & 0.323 & 0.353 & 0.301 & 0.240 & 0.304 & 0.330 & 0.360 & 0.309 \\
\hline Ascorbic acid (vit. C) & 0.269 & 0.307 & 0.345 & 0.368 & 0.322 & 0.274 & 0.315 & 0.351 & 0.376 & 0.329 \\
\hline Minia Azotein (M.A.) & 0.298 & 0.342 & 0.367 & 0.378 & 0.346 & 0.309 & 0.348 & 0.374 & 0.389 & 0.355 \\
\hline M.A. + vit. E & 0.304 & 0.363 & 0.377 & 0.401 & 0.361 & 0.312 & 0.371 & 0.387 & 0.413 & 0.371 \\
\hline M.A. + vit. C & 0.335 & 0.372 & 0.394 & 0.404 & 0.376 & 0.345 & 0.381 & 0.403 & 0.418 & 0.387 \\
\hline M.A. + vit. E + vit. C & 0.361 & 0.389 & 0.403 & 0.414 & 0.392 & 0.369 & 0.398 & 0.416 & 0.431 & 0.404 \\
\hline Mean (A) & 0.289 & 0.331 & 0.358 & 0.378 & & 0.297 & 0.340 & 0.367 & 0.389 & \\
\hline L.S.D. at $5 \%$ & \multicolumn{2}{|c|}{ A: 0.015} & B: 0.004 & \multicolumn{2}{|c|}{ AB: 0.008} & \multicolumn{2}{|c|}{ A: 0.019} & B: 0.006 & \multicolumn{2}{|c|}{ AB: 0.012} \\
\hline \multicolumn{11}{|c|}{ K \% } \\
\hline Control & 1.573 & 1.591 & 1.608 & 1.628 & 1.600 & 1.598 & 1.621 & 1.639 & 1.663 & 1.630 \\
\hline Alpha tocopherol (vit. E) & 1.582 & 1.600 & 1.619 & 1.640 & 1.610 & 1.610 & 1.632 & 1.658 & 1.677 & 1.644 \\
\hline Ascorbic acid (vit. C) & 1.593 & 1.617 & 1.639 & 1.664 & 1.628 & 1.622 & 1.653 & 1.676 & 1.697 & 1.662 \\
\hline Minia Azotein (M.A.) & 1.612 & 1.635 & 1.659 & 1.673 & 1.644 & 1.644 & 1.675 & 1.694 & 1.711 & 1.681 \\
\hline M.A. + vit. E & 1.614 & 1.644 & 1.670 & 1.689 & 1.654 & 1.650 & 1.688 & 1.709 & 1.729 & 1.694 \\
\hline M.A. + vit. C & 1.632 & 1.669 & 1.685 & 1.696 & 1.671 & 1.665 & 1.703 & 1.722 & 1.736 & 1.706 \\
\hline M.A. + vit. E + vit. C & 1.642 & 1.680 & 1.691 & 1.700 & 1.678 & 1.681 & 1.716 & 1.730 & 1.743 & 1.717 \\
\hline Mean (A) & 1.607 & 1.634 & 1.653 & 1.670 & & 1.639 & 1.670 & 1.690 & 1.708 & \\
\hline L.S.D. at $5 \%$ & \multicolumn{2}{|c|}{ A: 0.015} & B: 0.007 & \multicolumn{2}{|c|}{ AB: N.S. } & \multicolumn{2}{|c|}{ A: 0.017} & B: 0.010 & \multicolumn{2}{|c|}{ AB: N.S. } \\
\hline
\end{tabular}


nutrient elements uptake (Dewick, 2000). These positive effects of the used treatments led to promote nutrients uptake and finally reflect on the percentages of $\mathrm{N}, \mathrm{P}$ and $\mathrm{K}$.

The role of biofertilizer in improving $\mathrm{N}$, $\mathrm{P}$ and $\mathrm{K} \%$, which is in harmony with the obtained results was revealed by Mazhar and Eid (2016) and Sathyanarayana et al. (2018) on gladiolus, Fawzy et al. (2012) on onion, Parmar et al. (2017) on golden rod, Attia et al. (2018) on tuberose. Also, vitamin E increased $\mathrm{N}, \mathrm{P}$ and $\mathrm{K} \%$ as reported by Abdou et al. (2012, 2013a and 2013b) on mint, caraway and guar plants, respectively, and Mohamed (2016) on Antirrhinum majus plant. Vitamin C made a similar trend to increase these characters as reported by Abdel Aziz et al. (2009) and Abo Leila and Eid (2011) on gladiolus, Abdou and Mohamed (2014) on mint and Mohammed et al. (2016) on dahlia plant.

Effect of the interaction treatments was significant, in both seasons, for $\mathrm{N}$ and $\mathrm{P} \%$ only. The highest values were obtained with the interaction treatments of $20 \mathrm{~m}^{3} / \mathrm{fed} \mathrm{FYM}$ $\times$ M.A. + vit. $\mathrm{E}+$ vit. $\mathrm{C}$ as shown in Table (4).

\section{REFERENCES}

Abdel Aziz, G.N.; Taha, L. and Ibrahim, S.M.M. (2009). Some studies on the effect of putrescine, ascorbic acid and thiamine on growth, flowering and some chemical constituents of gladiolus at Nubaria. Ozean J. of Applied Sci., 2(2):169-179.

Abd El-Karim, F.M. (2001). Studies on Some Factors Affecting Growth, Flowering, and Bulb Productivity of Polianthus tuberosa, L. Plant. Ph.D. Thesis, Fac. Agric., Kafr El-Sheikh, Tanta Univ., Egypt.

Abdel-Sattar, M.M.; Ahmed, S.S. and Nabih, A. (2010). Response of tuberose (Polianthus tuberosa, L.) plant to different soil mixtures and ethephon under reclaimed desert soil. Egypt. J. Biotechnol., 35:185-206.
Abdou, M.A.H. and Ibrahim, T.I.E. (2015). Response of gladiolus cv. Carmen to compost, biofertilization and some vitamin treatments. Proc. $1^{\text {st }}$ Conf. of SSFOP "Future of Ornamental Plants in Egypt”, Scientific J. Flowers \& Ornamental Plants, 2(1):1-10.

Abdou, M.A.H and Mohamed, M.A.H. (2014). Effect of plant compost, salicylic and ascorbic acids on Mentha piperita, L. plants. Biological Agriculture \& Horticulture Journal, 30(2):131-143.

Abdou, M.A.H.; Attia, F.A.; Ahmed, E.T.; El-Sayed, A.A. and Abd-El-Naeem L.M. (2012). Physiological studies on mint plants. Proc. Second Inter. Conf. of Physiol. Microb. and Ecological Plant Sci. (29-30 April, 2012) Fac. Science, Minia Univ., pp: 207-228.

Abdou, M.A.H.; Attia, F.; Aly, M.K. and Sayed, I.H. (2004). Response of gladiolus plants to some bio and chemical fertilization treatments. 2- Corm production and chemical constituents. Proc. fifth Arabian Hort. Conf. Ismailia, Egypt 24-28, March (1):63-73.

Abdou, M.A.H.; Badran, F.S.; Ahmed, E.T.; Taha, R.A. and Abdel-Mola, M.A.M. (2018). Effect of compost and some natural stimulant treatments on: II. Corms production and chemical constituents of (Gladiolus grandiflorus cv. Peter Pears) plants. Proc. $4^{\text {th }}$ Conf. of SSFOP "Ornamental Plants and Environment”, Scientific J. Flowers \& Ornamental Plants, 5(2):115-126.

Abdou, M.A.H.; El-Sayed, A.A.; Attia, F.; Taha, R. and Shehata, A.M. (2013a). Effect of organic fertilization and natural substances on guar plants. Minia J. of Agric. Res. \& Develop., 33(2):221-242.

Abdou, M.A.H.; El-Sayed, A.A.; Taha, R.A. and Botros, W.S. (2013b). Physiological studies on caraway plants. Proc. $1^{\text {st }}$ Inter of Hort. Agric. Assuit, February 2013.

Abo-Hinna, M.A. and Merza, T.K. (2012). Effect of organic manure, tuber weight and ascorbic acid spraying on some vegetative parameters and marketable 
yield of potato (Solanum tuberosum, L.) grown in sandy soil. J. of Kufa for Agric. Science, 4(1):15-29.

Abo Leila, B. and Eid, R. (2011). Improving gladiolus growth, flower keeping quality by using some vitamins application. Journal of American Science, 7(3):169174.

Ahmed, A.S.A. (2013). Physiological Studies on Gladiolus Plant. M.Sc. Thesis, Fac. Agric. Minia Univ. Egypt.

Attia, K.E.; Elbohy, N.F.S.; Ashour, N.A.M. (2018). Response of tuberose plants (Polianthes tuberosa. L.) to chemical and bio fertilization and their effect on vegetative growth, flowering and chemical composition under sandy soil conditions. Scientific J. Flowers \& Ornamental Plants, 5(3):261-273.

Black, C.A.; Evans, D.D.; Evsminger, L.E.; White, J.L. and Clark, F.E. (1965). Methods of Soils Analysis. American Society of Agronomy. Inc. Publ. Madison, Wisconsin, USA, pp: 11621168.

Chakradhar, P.; Bohra, M.; Goutham, K. B.K. and Upadhyay, S. (2019). Response of biofertilizers on floral and yield attributing parameters of gladiolus (Gladiolus grandiflorus, L.) var. Arka Amar under hill conditions of Uttarakhand. Int. J. Pure App. Biosci., 7(1):157-161.

Champan, H.D. and Pratt, P.F. (1975). Methods of Analysis for Soil, Plant and Water Calif. Univ. Division of Agric. Sci., 172-174.

Cottenie, A.; Verloo, M.; Velghe, M. and Camerlynck, R. (1982). Chemical Analysis of Plant and Soil. Laboratory of Analytical and Agro Chemistry. State Univ., Ghent, Belgium.

Dadarwall, L.R.; Yadv, L.S. and Sindhu, S.S. (1997). Biofertilizer production: Technology: Prospects in Biotechnological Approach in Soil Microorganisms for Sustainable Crop
Production. Scientific Publishers, Jodhpur., India. pp: 323 - 337.

Dalawai, B. and Naif, B.H. (2017). Influence of nutrient sources on performance of carnation (Dianthus caryophyllus, L.) cv. Soto under naturally ventilated polyhouse. Journal of Pharmacognosy and Phytochemistry, 6(5):2049-2051.

Dewick, P.M. (2000). Medicinal Natural Products. A Biosynthetic Approach $2^{\text {nd }}$ Ed., John Wiley and Sons, N.Y., 306356.

Eid, R.A.; Taha, L.S. and Ibrahim, S.M.M (2010). Physiological studies on essential oil properties of Jasminum grandiflorum, L. as affected by some vitamins. Ozean Journal of Applied sciences, 3(1):87-96.

Eliwa, N.Y.; Rezk, B.B. and El-Shamy, M.A. (2009). Effect of organic and biofertilizer treatments on growth, flowering, bulbs production and chemical constituents of Iris tingitana cv. Wedgewood. J. Biol. Chem. Environ. Sci., 4: 441-461.

El-Morsy, A.H.; Ezzat, A.S. and Saif ElDeen, U.M. (2010). Effect of some phosphorus and potassium rates and foliar spray with antioxidants on growth, yield and yield quality of garlic (Allium sativum, L.), Annals of Agric. Sci., Moshtohor, 48(3):97-106.

El-Naggar, A.H. and El-Nasharty, A.B. (2009). Effect of growing media and mineral fertilization on growth, flowering, bulbs productivity and chemical constituents of Hippeatrum vittatum, Herb. American-Eurasian J. Agric. and Enviro. Sci., 6(3):360-371.

El-Sayed, A.; El-Hanafy, H.; Nabih, A. and Atowa, D.I. (2012). Raising Freesia refracta cv. Red Lion corms from cormels in response to different growing media and actosol levels. J. of Hort. Sci. Ornamental plants, 4(1):89-97.

Fadl, M.S. and Sari El-Deen, S.A. (1978). Effect of $\mathrm{N}$-benzyaladenine on photosynthetic pigments and total soluble sugars on olive seedling grown under 
saline conditions. Res. Bull. Agric. Ain Shams Univ., 843.

Fawzy, Z.F.; Abou El-Magd, M.M.; Yansheng, L. and Zhu, O. (2012). Influence of foliar application by E.M. (Effective microorganisms) amino acids and yeast on growth, yield and quality of two cultivars of onion plants under newly reclaimed soil. J. of Agric. Sci., 4(11):2639.

Gaber, K.M. (2019). Vegetative and flowering growth of geranium as affected by mineral fertilization and ascorbic acid foliar application. Middle East J. Appl. Sci., 9(1):220-230.

Gadagi, R.S.; Krishnaraj, P.U.; Kulkarni, J. H. and Tongmin, Sa. (2004). The effect of combined Azospirillum inoculation and nitrogen fertilizer on plant growth promotion and yield response of the blanket flower (Gaillardia pulchella). Scientia Horticulture, 100:323-332.

Hassan, A.A. (2013). Effect of Some Antioxidants on The Growth, Yield and Active Ingredients of Roselle Plants. M.Sc. Thesis, Fac. Agric., Minia Univ., Egypt.

Hassanein, M. M. and El-Sayed, S.G. (2009). Effect of some organic and biofertilization treatments on gladiolus plants: 2- Corm production and chemical constituents. J. Agric. Sci. Mansoura Univ., 34(6):6255-6268.

Hauwaka, F.I.A. (2000). Effect of using single and composite inoculation with Azospirillum brasilense, Bacillus megatherium var. phosphaticum and Glomus marcocarpus for improving growth of Zea mays. J. Agric. Sci., Mansoura Univ., 25 (1):239-252.

Ibrahim, T.I.E.I. (2014). Influence of Some Agricultural Treatments on Ammi visnaga Plants. Ph.D. Thesis, Fac. Agric., Minia Univ., Egypt.

Jackson, M.L. (1973). Soil Chemical Analysis Englewood Cliffs., New Prentice-Hall INC., New York.
Jagnow, G.; Hoflich, G. and Hoffman, K.H. (1991). Inoculation of non-symbiotic rhizosphere bacteria: Possibilities of increasing and stability yield. A new Botanik, 65: 97-126.

Karagöz, F.P.; Dursun, A.; Tekiner, N.; Kul, R. and Kotan, R. (2019). Efficacy of vermicompost and/or plant growth promoting bacteria on the plant growth and development in gladiolus. Ornamental Horticulture Journal, 25(2):180-188.

Kasim, J.Y. and Adil, A.M. (2014). Effect of gibberellic acid, spraying micronutrient and ascorbic acid in the vegetative growth, flowering of Freesia hybrida cv. Prominence. Journal of Kirkuk University for Agricultural Sciences, 5 (1):50-64.

Khalil, A.R.M. (2015). Physiological Studies on Gladiolus Plant. M.Sc. Thesis, Fac. Agric. Minia Univ., Egypt.

Khan, F.U.; Saddique, M.A.A.; Khan, F.A. and Nazki, I.I. (2009). Effect of biofertilizers on growth, flower quality and bulb yield in tulip (Tulipa gesneriana). Indian J. of Agric. Sci., 79(4):248-251.

Mathivanan, S.; Chidambaram, A.A.; Sundaramoorthy, P. and Kalaikandhan, R. (2012). Effect of vermicompost on germination and biochemical constituents of ground nut (Arachis hypogaea, L.) seedling. Int. J. of Res. In Biol. Sci., 2(2):54-59.

Mazhar, A.A.M. and Eid, R.A. (2016). Effect of various doses of chemical fertilizer (kristalon) individually or in combination with different rates of biofertilizer on growth, flowering, corms yield and chemical constituents of Gladiolus grandiflorus. International Journal of Pharm Tech Research, 9(12):139-145.

Mohamed, I.M.E. (2016). Effect of Some Physiological and Biological Treatments on The Growth, Flowering, Chemical and Anatomical Composition of Antirrhinum 
majus, L. Plant. Ph.D. Thesis, Fac. Agric., Cairo Univ., Egypt.

Mohammed, S.A.; Abd-Allatif, S.A. and Obaid, A.A. (2016). Effect of foliar application with potassium sulphate and ascorbic acid on growth and flowering of dahlia (Dahlia variabilis, L. cv. Arizona). Diyala for Agricultural Sciences Journal, 8(1):232-248, Iraq.

MSTAT-C (1986). A Microcomputer Program for the Design Management and Analysis of Agronomic Research Experiments (Version 4.0), Michigan State Univ., U.S.A.

Munne-Bosch, S. and Algere, L. (2002). The function of tocopherol and tocotrienol in plants. Crit. Rev. Plant Sci., 21:31-57.

Parmar, S.; Patel, R.B.; Chawla, S.L.; Bhatt, D. and Patel, K. (2017). Effect of chemical and bio-fertilizers on growth and flowering of golden rod (Solidago canadensis, L.) cv. "Local”. International Journal of Chemical Studies, 5(5):104108.

Pattnaik, S. (2016). Effect of Organic Manures on Growth and Flowering of Tuberose (Polianthes tuberosa) cv. Phule Rajani. M.Sc. Thesis, Orissa University of Agriculture and Technology.

Prasad, L.; Saravanan, S.; Lall, D. and Singh, V.K. (2017). Effect of organic manure and inorganic fertilizer on plant growth and flower yield of Asiatic lily (Lilium longiflorum) cv. Zephyranthes. Environment \& Ecology J., 35 (2A):929932.

Ramraj, V.M.; Vyas, B.N.; Godrej, N.B.; Mistry, K.B.; Swami, B.N. and Singh, N. (1997). Effect of 28-homobrassinolide on yields of wheat, rice, groundnut, mustard, potato and cotton. Jour Agric. Sci., 128: 405-413.

Sathyanarayana, E.; Patil, S.; Bahubali, M. and Chawla, S.L. (2018). Effect of INM on gladiolus (Gladiolus grandiflorus, L.) cv. American beauty under Navsari and
Tansa conditions. Int. J. Pure App. Biosci., 6 (4):48-55.

Shalaby, T. and El-Ramady, H. (2014). Effect of foliar application of biostimulants on growth, yield, components and storability of garlic (Allium sativum, L.). Australian Journal of Crop Science, 8(2):271-275.

Sönmez, F., Cig, A.; Gülser, F. and Basdogan, G. (2013). The effects of some organic fertilizers on nutrient contents in hybrid gladiolus. Eurasian Journal of Soil Science 2:140-144.

Srivastava, R.; Preetham, S.P. and Chand, S. (2014). Effect of organic manures and biofertilizers on vegetative, floral and post-harvest attributes in tuberose (Polianthes tuberosa) var. Shringar. Asian J. Biol. Life Sci., 3(1):6-9.

Suseela, T.; Chandrasekha, R.; Vijaya, V.; Bhaskar, D.R.; Suneetha, S. and Umakrishna, K. (2016). Effect of organic manures, inorganic fertilizers and micronutrients on vegetative and floral characters of tuberose (Polianthes tuberosa, L.) cv. 'Suvasini'. International Journal of Scientific and Research Publications, 6(2):170-173.

Taha, R.A. and Hassan, A.H. (2008). Response of gladiolus plants to mineral bio-fertilization and bio-fertilization treatments. 2- Corm production and chemical constituents. Alex. J. Agric. Res., 53:87-95.

Wilde, S.A.; Covey, R.P.; Lyer, J.C. and Voigt, G.K. (1985). Soil and Plant Analysis for Tree Culture. Oxford, IBH. Publishing Co., New Delhi, India.

Zhang, R.; Schmidt, E. and Zhang, X.Z. (2000). Hormone containing products impact on antioxidants status of tall fescue and creeping betagrass subjected to drought. Crop. Sci., 40:1344-1349. 


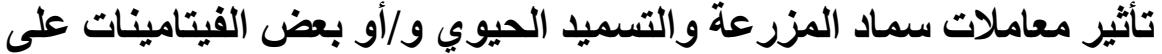 \\ بـ انتاج الكورمات والكريمات وبعض الصفات الكيميائية لنباتات الجلاديولس صنف Gold Field
}

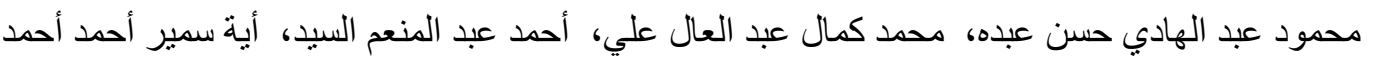

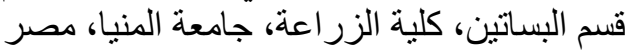

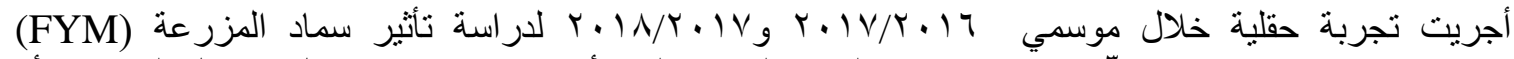

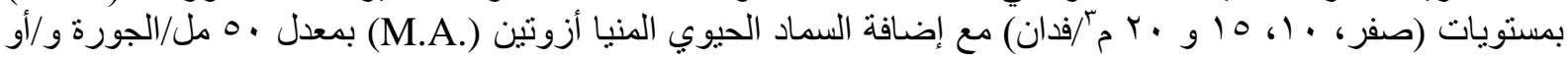

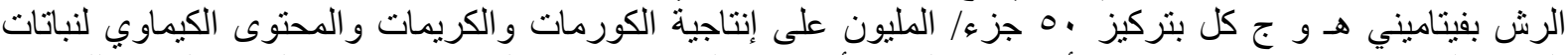

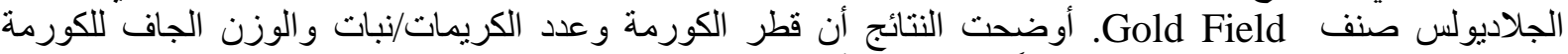

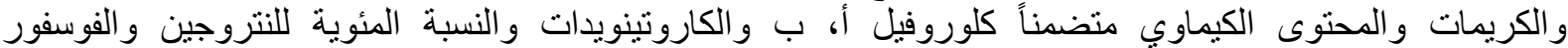

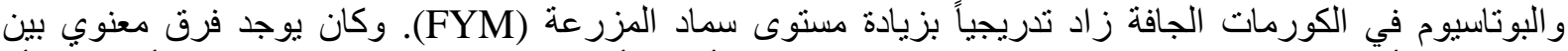

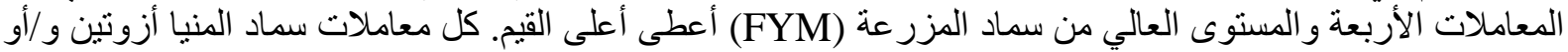

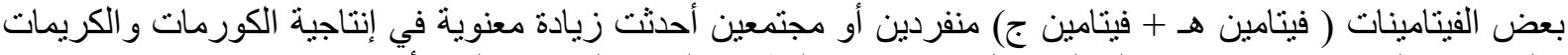

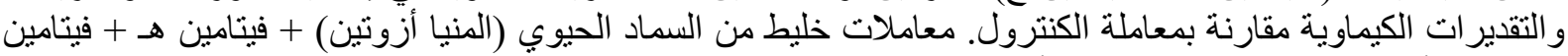

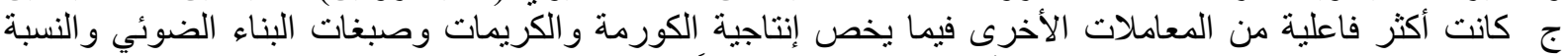

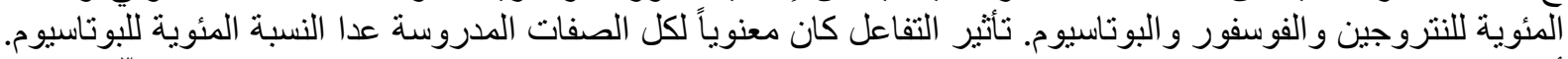

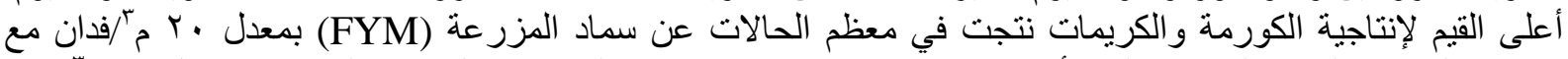

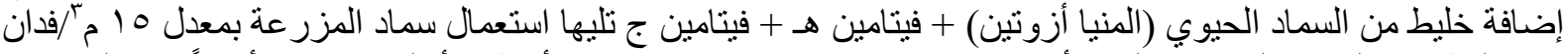

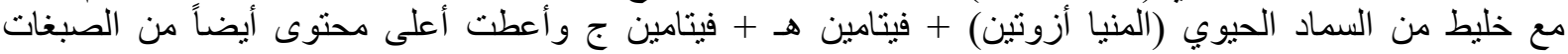
و عنصري النتروجين و الفوسفور الكيط 